\title{
Miten olla queer?
}

\section{Mikko Carlson: Paikantuneita haluja. Seksuaalisuus ja tila Christer Kihlmanin tuotannossa. Jyväskylä: Nykykulttuuri, 20 I4. 353 s.}

Mikko Carlsonin väitöskirja kohdentuu Suomessa suhteellisen niukalti tutkittuun kotimaisen nykykirjallisuuden kauteen, 1970- ja 1980-lukuun, ja yhtä säästeliäästi tutkittuun Christer Kihlmanin kirjalliseen tuotantoon. Tutkielman aineisto koostuu Kihlmanin teoksista Människan som skalv ( I97I), Dyre prins (1975), Alla mina söner (1980), Livsdrömmen rena (1982), På drift i förlustens landskap (1986) ja Gerdt Bladhs undergång (1987) eli teoksista, joissa koetellaan julkaisuajankohtinaan uskaliaalla tavalla seksuaalisuuteen liitettyjä kulttuurisia normeja. Toisissa teoksissa normeja koetellaan näkyvämmin, toisissa peitellymmin. Carlsonin mukaan teema on kuitenkin luettavissa niistä kaikista. Väitöskirjan tutkimustavoitteissa tartutaan juuri tähän: tavoitteena on tarkastella, miten normienvastainen tai antinormatiivinen seksuaalisuus jäsentyy ja merkityksellistyy Kihlmanin 1970-1980-luvun romaaneissa. Tutkimus pyrkii osoittamaan, että seksuaalisuuden esityksiä uudelleenjäsentämällä ja -merkityksellistämällä koko aiemmin tuotettu kuva Kihlmanin tuotannosta ja kirjailijuudesta muuttuu. Lisäksi tavoitteena on tutkia, miten seksuaalisuus, ja ennen kaikkea normeihin alistumaton seksuaalisuus ja seksuaalinen halu, representoituvat Kihlmanin teoksissa tilallisesti.

Väitöskirjan keskeisin teoreettinen viitekehys rakentuu queertutkimuksen pohjalle. Juuri queer-teoreettinen tausta tarjoaa mahdollisuuden niille uudenlaisille tulkinnoille ja johtopäätöksille, joita työssä tehdään. Sama pätee tutkimusongelman ja sitä tukevien tutkimuskysymysten asetteluun. Muun muassa feministisestä teoriasta ja sukupuolentutkimuksesta ponnistava queer-teoria vaikuttaa tässä mielessä sekä koko tutkimuksen alkuasetelmaan että sen metodologiaan - siihen, mitä aineistoja tutkitaan (tutkimuskohde), mitä ja miten aineistolta kysytään (tutkimusongelma), miten sitä analysoidaan ja tulkitaan (tutkimuksen menetelmät) ja miksi tutkimusta ylipäätään tehdään (tutkimuksen motivointi ja merkitys). Tätä metodologista tutkimuksen ja sen taustojen esittelyä sekä reflektointia olisin toivonut työhön enemmänkin. Se olisi jäsentänyt rakenteellisesti itse tutkielmaa, selventänyt konteksteja ja edistänyt etenkin queer-teorian tulevaisuuden käyttömahdollisuuksia.

Tutkimustehtävää väitöskirjassa toteutetaan kolmesta, tutkimusaineistoja hieman eri kulmista lähestyviin tutkimusmenetelmiin sitoutuvasta näkökulmasta. Tavoitteena on yhtäältä lukea Kihlmanin teoksia tekstilähtöisesti, tekstuaalis-rakenteellisesti, temaattisesti ja kontekstuaalisesti. Toisaalta näitä ehkä jopa keskeisemmäksi tavoitteeksi tulee Kihlmanin tekijyyden/kirjailijuuden kriittinen tarkastelu kirjallisuusinstituutiossa ja sen osana. Carlson näkee Kihlmanin aseman suomalaisessa ja 
suomenruotsalaisessa kirjallisuusinstituutiossa tilana, ”jonka yhteydessä kysymykset intellektuelli- ja homokirjailijuuden sidoksista avaavat reitin Kihlmanin ristiriitaisen kirjailijakuvan uudelleenarviointiin”. Hypoteesina esitetään, että seksuaalisuuden kulttuurinen moniselitteisyys sekä siihen liittyvä epävarmuus, rajattomuus ja häilyvyys ovat Kihlmanin teosten keskeisimpiä teemoja. Itse tutkimus osoittaa, että samat teemat koskettavat myös Kihlmanin kirjailijakuvaa. Samalla tilallisuuden käsite tulee osaksi teosten analyysejä ja tulkintaa sekä Kihlmanin kirjailijakuvan ja suomalaisen ja suomenruotsalaisen kirjallisuusinstituution tarkastelua.

Kihlmanin kirjailijakuva muodostuu toki ennen kaikkea hänen teostensa myötä, joten niitäkin on syytä hieman käsitellä. Carlsonin työ muistuttaa muun muassa siitä, että vuonna 1971 ilmestyneessä, omaelämäkerrallisen ja tunnustuskirjallisuuden konventioita hyväkseen käyttävässä, esseistiseksi tai pamfletiksikin helposti määriteltävässä Människan som skalv-teoksessa homoseksuaalisuuteen liittyvä tekstuaalisen tunnustamisen akti muodostui julkaisuajankohtanaan näkyväksi seksuaalipoliittiseksi teoksi. Näin kävi etenkin siksi, että kirja on kirjoitettu ja julkaistu aikana, jolloin homoseksuaalisuus vielä miellettiin Suomessa tabuksi ja rikokseksi. Dyre prins ja Gerdt Bladhs undergång puolestaan muodostavat Människan som skalv -teoksesta ainakin pinnallisesti tarkasteltuna poikkeavan teosparin, jossa kuvataan enimmäkseen ironiseen sävyyn yläluokkaisen mahtisuvun rappioitumista. Alla mina söner, Livsdrömmen rena ja På drift i förlustens landskap puolestaan liittyvät Kihlmanin tuotannon kiusallisena pidettyyn kauteen, jolloin omaelämäkerralliset, ja nimenomaan seksuaaliset, ainekset puskivat vastaanoton mukaan liikaa pintaan. Teokset tulkittiin Människan som skalviin palaaviksi, vanhan lämmittelyiksi sen sijaan, että ne olisi nähty autofiktiivisen kirjallisuuden lajiominaisuuksia haastavana jatkumona - puhumattakaan siitä, että niitä olisi pystytty julkaisuajankohtanaan pitämään osana autofiktiivistä kirjallisuutta, jossa hahmotellaan mahdollisuuksia saavuttaa tekstuaalisia ja queereja (halun) tiloja sekä paikkoja. Tai paikantuneita haluja, kuten Carlson asian ilmaisee. Carlsonin tutkimuksen kehyksessä Kihlmanin koko kirjallista tuotantoa läpäisevä lajirajojen aktiivinen haastaminen tulee sekin näkyväksi, ja sen hahmottaminen tilallisesti tuottaa uusia, mielenkiintoisia merkitysyhteyksiä myös Kihlmanin teosten sisällölliseen ja temaattiseen tarkasteluun.

Carlsonin tutkimus osoittaa, että tilan käsitteen avulla seksuaalisuuden moninaisuutta, häilyvyyttä, välitilaisuutta ja dynaamisuutta voidaan tarkastella uusia tulkintanäkymiä avaavalla tavalla. Tämän lisäksi Carlsonin tutkimusta kehämäisesti kiertäväksi lisätutkimustehtäväksi tai -ongelmaksi näyttäisi muotoutuvan kysymys siitä, miten olla queer ja miten olla sitä eri konteksteissa ja etenkin sellaisissa ajoissa ja paikoissa, jotka eivät lähtökohtaisesti normienvastaisuutta hyväksy. Näihin kysymyksiin työ tarjoaa vastauksia, joita lukija ei osaa ennalta edes odottaa.

Carlsonin väitöskirja on ajankohtainen lisä sekä kirjallisuuden- että queer-teoreettiseen tutkimukseen Suomessa. Se tarjoaa teoreettisesti uudenlaisen tavan lukea ja tulkita Kihlmanin teoksia sekä niiden kon- 
teksteja. Uusi näkökulma laajentaa tutkimuksen merkityspotentiaalia yksittäisen kirjailijan teosten tarkastelusta koskemaan laajemmin koko kotimaisen kirjallisuusinstituution sekä suomalaisen ja suomenruotsalaisen kirjallisuuden tutkimusta. Toivoa sopii, että väitöskirjan merkitys myös nähdään kotimaisen (nyky)kirjallisuudentutkimuksen ja suomenruotsalaisen kirjallisuudentutkimuksen kentällä.

\section{Kirjoittaja}

Sanna Karkulehto, kirjallisuuden professori, Taiteiden ja kulttuurin tutkimuksen laitos, Jyväskylän yliopisto

(sanna.karkulehto[at]jyu.fi) 
1 